(RESEARCH ARTICLE)

\title{
Comparing the early growth performance of plantation-grown Eucalyptus hybrid and Eucalyptus pellita, South Johore, Peninsular Malaysia
}

\author{
Yahya Ahmad Zuhaidi 1, $^{*}$, Hassan Nor Hasnida ${ }^{2}$, Loon Ng Tong ${ }^{3}$, Heng Lai Hong ${ }^{3}$ \& Zorkarnain Fauzeyana \\ Ain 3 \\ ${ }^{1}$ Fellowship, Forest Research Institute Malaysia, 52109 Kepong, Selangor, Malaysia. \\ ${ }^{2}$ Research Officer, Forest Biotechnology Division, Forest Research Institute Malaysia, 52109 Kepong, Selangor, Malaysia. \\ ${ }^{3}$ Aramijaya Sdn Bhd, G 12 \& 14, Block 6, Jalan Skudai, Danga Bay, 80200 Johore Bahru, Malaysia.
}

Publication history: Received on 14 May 2020; revised on 25 May 2020; accepted on 27 May 2020

Article DOI: https://doi.org/10.30574/wjarr.2020.6.2.0157

\begin{abstract}
Eucalyptus spp. is an important species in the worldwide quality tropical hardwood sector, which has also gained significance in Sabah and Sarawak, Malaysia since the first large plantations established in 2008s. In October 2018, the trial planting of Eucalyptus hybrid (E. grandis x E. urophylla) and Eucalyptus pellita F. Muell was conducted in Hulu Sedili Forest Plantations, Kota Tinggi, Johore a tropical site with year-round high rainfall and humidity. The $E$. hybrid were formerly raised using tissue culture technique in the laboratory, Forest Research Institute Malaysia (FRIM) using the plantlets introduced from Tawau, Sabah. While the E. pellita seedlings were conventionally raised from seeds obtained from Seed Production Areas in Sabah Softwood Bhd, Tawau. After 18 months, it was clear that diameter, height growth and periodic increments of $E$. hybrid out performed $E$. pellita in the humid tropical environment. The average diameter at breast height, total height, periodic annual diameter and height increments of $E$. hybrid were significantly different in comparison with E. pellita. The initial vegetative measurement revealed the growth performance of Eucalyptus hybrid with respect with achieved diameter at breast height and total height was higher as compared with Eucalyptus pellita with good survival rate of greater than 90 percent.
\end{abstract}

Keywords: Tissue culture; Seed; Periodic annual increments; Hulu Sedili Forest Reserve

\section{Introduction}

The capacity of existing natural forest is slowly decreasing in its capability meeting the increasing demand of round logs for the domestic wood processing industries. In an effort to reduce reliance on natural round logs from natural forests and as strategy to overcome the problem of scarcity, forestry companies and investors in Malaysia has initiated the programme of commercial planting of selected fast growing species for continuous wood supply. In this programme both native and exotic species was selected for planting including Neolamarckia cadamba, (A. Zuhaidi 2012) [1] or kelempayan (laran), Paraserianthes falcataria (batai) and Eucalyptus spp (A. Zuhaidi 2020 [2]; A Zuhaidi 2019 [3]). The planting programme was partly caused by the recent outbreak of wilt disease by Ceratocystis spp. causing 10 to $20 \%$ death of the plantation tree species in particular the Acacias (Wong et al. 2015) [4]. The planters in Sabah and Sarawak reacted to this situation by switching to Eucalyptus species such as E. pellita and Eucalyptus hybrid in areas formerly planted with Acacias. Both species has been well accepted as plantation species and by the end 2015, a total of 11,000 ha and 28,090 ha of both E. hybrid and Eucalyptus pellita plantations have been established in Sabah and Sarawak (Wong et al. 2015) [4]. The E. hybrids formerly introduced from Southern China have been satisfactorily trial planted in various parts of Sabah as pilot plantations, with the oldest recorded stands since 2008 in Sabah Softwood Berhad, Tawau.

Arnold et al. (2017) [5] reported the hybrid clone, crossing between E. grandis and E. urophylla has been widely accepted and planted in plantations due to its stability and other superiorities including growth, high rate of survival

*Corresponding author: Yahya Ahmad Zuhaidi Email: zuhaidi@frim.gov.my

Copyright (C) 2020 Author(s) retain the copyright of this article. This article is published under the terms of the Creative Commons Attribution Liscense 4.0. 
and wide range of adaptability. The clone covers for over $60 \%$ of the hybrid plantation establishment across Southern China. The recorded growth and yield of 11.5-year-old clones in Quangxi, China yielded $555.95 \mathrm{~m}^{3} /$ ha equivalent to the mean annual volume increment of $48.34 \mathrm{~m}^{3} / \mathrm{ha}$ /year. The average height and diameter at breast height were $26.8 \mathrm{~m}$ and $20.3 \mathrm{~cm}$.

Harwood et al. (1997) [6] studied the early growth and survival of Eucalyptus pellita provenances in a range of tropical environments, comparing with E. grandis, E. urophylla and Acacia mangium. After 2-3 years, it was clear that New Guinea provenances outperformed Queensland provenances in their survival, growth and form, and in their crown health, in the humid tropical environment. Melesse \& Zewotir (2017) [7] evaluated the variations in the growth potential of two clones planted in Queensland based on average stem radial growth advantage. The study showed that Eucalyptus grandis $\times$ Eucalyptus urophylla clone grew faster than the E. grandis $\times$ camaldulensis clone, indicating better genetic potential for rapid growth and yield. The present work highlights the results from an early growth performance of the two Eucalyptus species planted in the humid tropical environment in Peninsular Malaysia as part of the future expansion work.

\section{Material and methods}

\subsection{Materials}

The study was conducted in Block 10 A-C, Site V Hulu Sedili Forest Reserve, Kota Tinggi, Johore, located at latitude 1.95 ${ }^{\circ}$ North and longitude $103.87^{\circ}$ East. The site was formerly intercropped with vegetables farming until November 2019. The mean annual temperature ranges from 26 to $33^{\circ} \mathrm{C}$, with mean annual rainfall from 2000 to $2400 \mathrm{~mm}$ and the number of rainy days varies from 89 to 189 days. The site has an altitude ranges from 75 to $120 \mathrm{~m}$ above sea level, with flat and undulating terrain. The soil series consists of soils developed over acid igneous rocks, iron coated sedimentary rocks (shales, sandstones), pediments and recent alluvial deposits (Anonymous, Soil Survey Report 2017) [8]. The soil texture consist of light reddish sandy loam and former vegetation mainly of remaining A. mangium plantations partly harvested in 2010 and some secondary forest tree species.

Three plots consisting of 100 and 200 plantlets of E. hybrid and E. pellita and with two replicates were established in October 2018 in Block 10 A-C, Site V, Hulu Sedili Forest Reserve, Kota Tinggi, Johore. The average initial height of the plantlets ranges from 0.6 to $0.8 \mathrm{~m}$. The plantlets were planted at $3 \times 6 \mathrm{~m}$ equivalent to $555 \mathrm{stems} / \mathrm{ha}$ as there are still remaining vegetables between lines. Manuring was done during the planting using Christmas Island Rock Phosphate (CIRP) at 100 g per plant, followed by $200 \mathrm{~g}$ of NPK (Nitrogen: 15, Phosphate: 15, Potassium; 6 and Trace Element 4) after 6 months planting.

\subsection{Methods}

The materials used in the trial planting study were formerly raised by tissue culture technique in the laboratory, Forest Research Institute Malaysia (FRIM) using the plantlets introduced from Tawau, Sabah. While the E. pellita seedlings were conventionally raised from seeds obtained from Seed Production Areas in Sabah Softwood Bhd, Tawau.

During the first 6 months, singling was carried out, removal of multiples leaders and brashing of dead branches along the first $1 \mathrm{~m}$ of the stem. However, strong wind in Hulu Sedili Forest Reserve in July, 2019 has caused some of the smaller size $E$. hybrid ( $2 \%$ ) being uprooted. The removal of these branches help in the free flowing of air around the basal part of the trees and gaining access into the stand.

The total tree height ( $h t$ in meters) and diameter at breast height ( $d$ graduated in centimeters) were measured twice in July 2019 and April 2020 using YAMAYO height stick and metal metric diameter tape at $1.3 \mathrm{~m}$ above ground level.

The periodic annual diameter and height increments were calculated as in Equation 1 and 2.

The periodic annual diameter increment (PAId) and periodic annual height increment (PAIh) were calculated as:

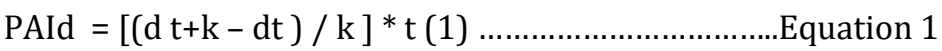

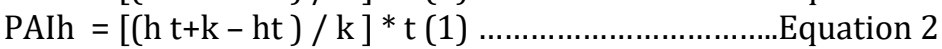

Where;

PAId $=$ observed periodic annual diameter increment $\left(\mathrm{cm}_{\text {year-1}}{ }^{-1}\right)$

PAIh $=$ observed periodic annual height increment $\left(\mathrm{m}\right.$ year $\left.{ }^{-1}\right)$

$\mathrm{dt}+\mathrm{k}=$ diameter at the end of growth period $(\mathrm{cm})$ 
$\mathrm{ht}+\mathrm{k}=$ total height at the end of growth period $(\mathrm{m})$

$\mathrm{dt}=$ diameter at the beginning of growth period $(\mathrm{cm})$

$\mathrm{ht}=$ total height at the beginning of growth period $(\mathrm{m})$

$\mathrm{k}=$ length of growth period (days);

$\mathrm{t}=365$ days

The periodic annual diameter and total height increment between 2019 and 2020 was expressed as an average of all annual increments over the growth period.

\subsection{Analyses of data}

Statistical analyses to determine the relationship between means growth of both species was analyzed using SAS/ STAT 20199.4 repeated analysis of variance. PROC GLM (Generalized Linear Model) was used since two diameter and height measurements obtained on the same trees from 2019 to 2020. Duncan's Multiple Range Test (DMRT) was used to determine differences between means.

\section{Results and discussion}

The figures in Table 1 summarized the details of the stands and growth performance established in October 2018 and measured in July 2019 and April 2020. The results from the measurement revealed that the growth performance of Eucalyptus hybrid in term of total height (ht), diameter at breast height (d) and periodic annual increment (PAI) are significantly higher as compared with Eucalyptus pellita in both plots P6 and P12, with good survival rate of greater than 90 percent. Subsequently, the graph in Figure 1 illustrated the breakdown of diameter distribution between three measurements period.

Table 1 Summary on the early growth performances of both Eucalyptus hybrid and Eucalyptus pellita, Hulu Sedili Forest Plantation, South Johore, in April 2020.

\begin{tabular}{llllllll}
\hline Species & $\begin{array}{l}\text { Age } \\
\text { (year) }\end{array}$ & $\begin{array}{l}\text { Average } \\
\text { ht (m) }\end{array}$ & $\begin{array}{l}\text { Average } \\
\mathbf{d}(\mathbf{c m})\end{array}$ & $\begin{array}{l}\text { PAIh } \\
\text { (m) }\end{array}$ & $\begin{array}{l}\text { PAId } \\
\text { (cm) }\end{array}$ & $\begin{array}{l}\text { Trees } \\
\text { (n) }\end{array}$ & $\begin{array}{l}\text { Survival } \\
\text { (\%) }\end{array}$ \\
\hline Eucalyptus hybrid & 1.49 & $10.94 \mathrm{a}$ & $8.2 \mathrm{a}$ & $1.00 \mathrm{a}$ & $3.4 \mathrm{a}$ & 81 & 94.95 \\
Eucalyptus pellita (P6) & 1.34 & $6.11 \mathrm{~b}$ & $6.9 \mathrm{~b}$ & $0.43 \mathrm{~b}$ & $2.5 \mathrm{~b}$ & 214 & 98.31 \\
Eucalyptus pellita (P12) & 1.34 & $5.81 \mathrm{~b}$ & $6.4 \mathrm{~b}$ & $0.47 \mathrm{~b}$ & $3.1 \mathrm{a}$ & 176 & 99.55 \\
\hline
\end{tabular}

NB. Values in each column with the same letter are not significantly different

$\mathrm{Ht}$-total height $(\mathrm{m}) ; \mathrm{d}$ - diameter at breast height $(\mathrm{cm})$; PAIh - periodic annual height increment; PAId -periodic annual diameter increment
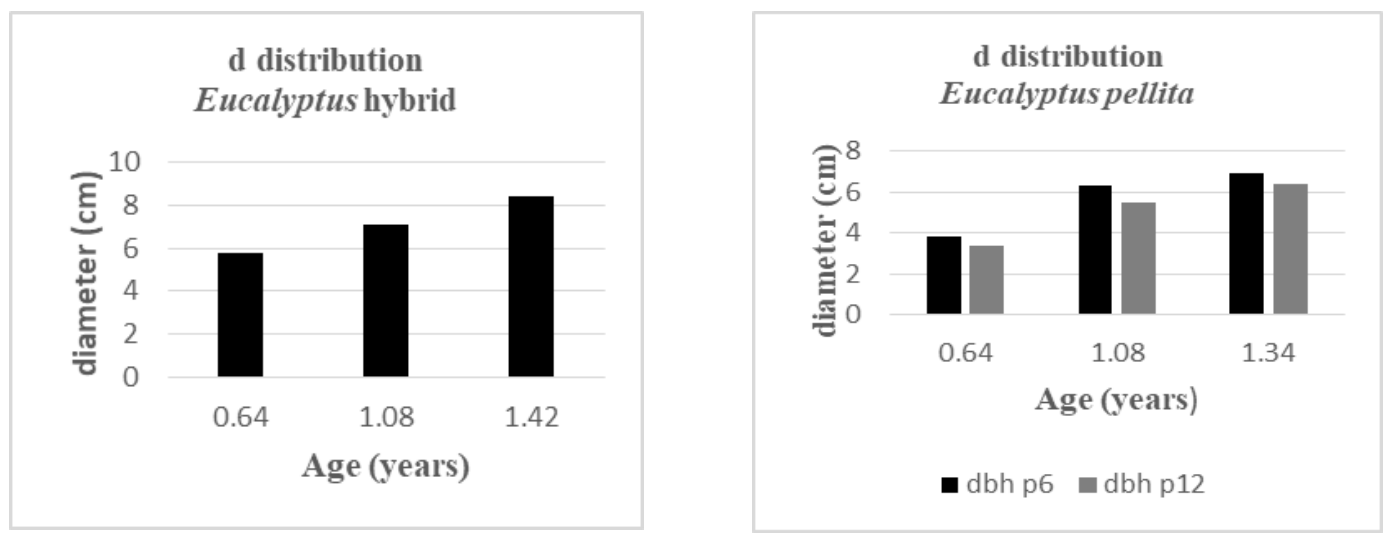

Figure 1 Diameter (d) distribution between both species measured at three observation periods

The results from the data analyses (Table 1) showed that significant differences were observed between both height and diameter growth, and periodic increments of $E$. hybrid and E. pellita in all plots, P6 and P12. The periodic annual height and diameter increments during the period 2019 to 2020 ranged from 0.43 to $1.00 \mathrm{~m}$; and 2.5 to $3.4 \mathrm{~cm}^{\mathrm{year}}-1$ 
respectively. The ranking based on DMRT showed that the periodic annual height and diameter increment of $E$. hybrid were statistically significant with E. pellita in plot P6 but not statistically significant with plot P12. Subsequently, higher average diameter and height of $E$. hybrid may to some extent caused by the exclusion of smaller size trees that have been uprooted during the strong wind in July 2019. McComb et al. 1997 [9] in his study has indicated that $E$. hybrid were easily fallen due to strong wind as trees raised in tissue culture have many adventitious roots rather than single tap root produced using seedlings.

The results from this study concurs with Melesse \& Zewotir (2017) [7] that the hybrid (Eucalyptus grandis $\times$ Eucalyptus urophylla) clone grew faster indicating better genetic potential for rapid growth.

Teguh (2016) [10] evaluated the early growth of planted E. pellita in Central Java using clones from plus trees and bulk seeds of 11 year old plantation as control. After 2 years, the clone achieved mean height and diameter ranges from 7.70 to $8.49 \mathrm{~m} ; 6.0$ to $6.3 \mathrm{~cm}$ as in the control at $5.64 \mathrm{~m}$ and $4.8 \mathrm{~m}$ respectively. The height growth values were slightly higher than those achieved from the current study using seeds as the source of planting materials

In support of the results from this study, field planting studies of E. pellita in both fertile and degraded sites have been conducted in Samarahan, Sarawak and Selandar F.R.in Jasin, Peninsular Malaysia. The annual diameter and height increment of 5-year-old E. pellita stand established in November 2010, Samarahan, Sarawak were comparable at 3.4 $\mathrm{cm}$ and $2.28 \mathrm{~m}$ respectively. While the studies in Selandar F.R. formerly of log landing areas showed lower growth rate after 5 years of planting at $1.6 \mathrm{~cm}$ and $1.67 \mathrm{~m}$ respectively (A Zuhaidi et al. 2018) [11].

\section{Conclusion}

After 18 months, it was clear that the early growth performance of $E$. hybrid, originating from Southern China outperformed E. pellita in both diameter and height growth. Significant differences were observed in diameter at breast height, total height, periodic annual diameter and height increment. The results from this study may be used as the starting point to further analyzing the potential on the growth of both E. hybrid and E. pellita in Malaysia by extending the data compilation. Continuous study may be conducted to monitor the performance of $E$. hybrid as compared with $E$. pellita developed using seeds with the presence of tap root.

\section{Compliance with ethical standards}

\section{Acknowledgements}

The authors are thankful to the management and staff of Aramijaya Sdn Bhd for the facility and field assistance in carrying the study and data collection. Our special thanks to the Director General FRIM for the support in the working collaboration between FRIM and Aramijaya Sdn Bhd.

\section{Disclosure of conflict of interest}

"The authors have no conflicts of interest to declare. All co-authors have seen and agree with the contents of the manuscript and there is no financial interest to report. We certify that the submission is original work and is not under review at any other publication"

\section{References}

[1] Ahmad Zuhaidi Y. (2012). Evaluating the Growth Performance of 4-year-old Neolamarckia cadamba in Malaysia: The Planter, 88(1038), 100-107.

[2] Ahmad Zuhaidi Y. (2020).Planting of Eucalyptus in Malaysia. ACTA Scientific Agriculture, 4(2), 1-2.

[3] Ahmad Zuhaidi Y. (2019). Are we ready to commercialize Eucalyptus hybrid and E. pellita? FRIM in Focus, 12-13.

[4] Wong SK, Ahmad Zuhaidi Y, Charles GDC and Peter KCS (2015). Recommending Eucalyptus Species for Soft Loan Financing. Working paper presented at the 1st Technical Meeting on Forest Plantation Programme, Malaysian Timber Industry Board (MTIB), Kuala Lumpur.

[5] Arnold R, Xie Y, Wu Zhihua, Chen S, Apeng DU and Luo J. (2017). Advances in eucalypt research in China. Frontiers of Agricultural Science and Engineering, 4, 10. 
[6] Harwood C, Alloysius D and Pomroy P. (1997). Early growth and survival of Eucalyptus pellita provenances in a range of tropical environments, compared with E. grandis, E. urophylla and Acacia mangium. New Forests 14, 203-219.

[7] Melesse SF and Zewotir T. (2017). Variation in growth potential between hybrid clones of Eucalyptus trees in eastern South Africa. Journal of Forestry Resource, 28, 1157-1167.

[8] Anonymous. (2017). Soils Reports of Hulu Sedili Estate, Mukim Mersing, Mersing District, Johor, Malaysia, Felda Agricultural Services Sdn Bhd, Kuala Lumpur, Malaysia, 22 .

[9] McComb JA, Steel E, Bell DT, van der Moezel, Bennett IJ, Dell B and Colquhoun I. (1997) Root Growth of Seedlings and Tissue Cultured Plants of Eucalyptus. In: Altman A. \& Waisel Y. (Eds.) Biology of Root Formation and Development. Basic Life Sciences, 65. Springer, Boston, MA. 259-265.

[10] Teguh S, Sunarti, S and Arif Nirsatmanto. (2016). Early Growth and Stand Volume Productivity of Selected Clones of Eucalyptus pellita, Indonesian Journal of Forestry Research, 3(1), 27-32.

[11] Ahmad Zuhaidi Y, Dasrul Iskandar D and Ng TL. (2018). Status of Commercial Planting of Eucalyptus in Malaysia. Paper presented at the 4th World Congress on Planted Forests, A Solution for Green Development, Beijing, China.

\section{How to cite this article}

Yahya AZ, Hassan NH, Loon NT, Heng LH and Zorkarnain FA. (2020). Comparing the early growth performance of plantation-grown Eucalyptus hybrid and Eucalyptus pellita, south Johore, Peninsular Malaysia. World Journal of Advanced Research and Reviews, 6(2), 234-238. 